\title{
BREVE CONSIDERAÇÃO SOBRE A GERMINAÇÃO DE SEMENTES DE COPAÍBA (Copaifera officinalis L.)
}

\author{
Martinho Alves de Andrade Júnior ${ }^{1}$
}

\begin{abstract}
Em áreas de mata de galeria do rio Branco ocorrem espécies florestais arbóreas de porte considerável. Copaifera officinalis é uma das espécies mais características destas áreas, a partir de Caracaraí (sentido Sul - Norte). Na região dos campos (áreas de "lavrado" ou savana), próximo à Boa Vista e São Marcos, está representada por exemplares de pequeno porte (DUCKE, 1949²).

Sementes colhidas sob a copa de duas árvores-matrizes, situadas em área de mata de galeria próxima ao Distrito Industrial de Boa Vista/RR, em duas datas (17 e 20/ 05/ 1995), foram semeadas em areia e conduzidas a pleno sol, com regas diárias. Utilizou-se 4 repetições de 25 sementes, para cada árvore-matriz.

O início da germinação das sementes da matriz 1 ocorreu aos 15 dias e da matriz 2 aos 17 dias, após a semeadura. A germinação obtida foi muito baixa, com resultados de $24 \%$ e 10\%, respectivamente (Fig. 1). No final do experimento não foram observadas sementes duras.

A inexistência de outros dados relativos a germinação (como por exemplo o Teor de Água das sementes) limitam o aprofundamento na discussão dos resultados. No entanto, as respostas obtidas sugerem a necessidade de estudos, com o intuito de compreender a dinâmica da germinação de sementes de c. officinalis.
\end{abstract}

\footnotetext{
1 Museu Integrado de Roraima/Setor de Botânica

2 DUCKE, Adolfo. 1949. As leguminosas da Amazônia brasileira. In: Notas sobre a flora neotrópica - II Boletim Técnico do Instituto Agronômico do Norte, 18. 2a. ed. Belém, Pará.
}

Bol. do Mus. Integrado de Roraima, Boa Vista, 4 (único): 49-50, 1998 


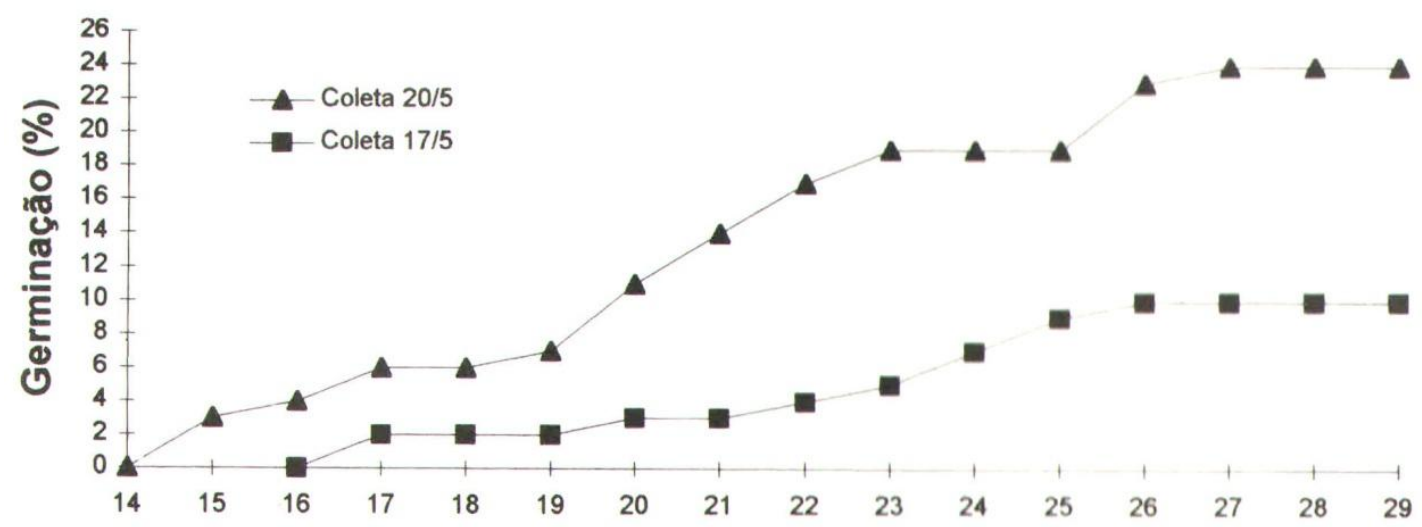

Dias após a semeadura

Fig. 1 - Germinação de sementes de Copaifera officinalis L. em função de árvore-matriz e data de coleta.

Fig. 1.Germinação das sementes de Copaifera officinalis L.

Recebido em:05.06.96

Aceito em:07.08.96

Bol. do Mus. Integrado de Roraima, Boa Vista, 4 (único): 49-50, 1998 